\title{
Afterword: Academics, Pentecostals, and Witches: The Struggle for Clarity and the Power of the Murky
}

\author{
Peter Geschiere
}

One of the many strong points of this collection is that it vividly shows the kaleidoscopic character of phenomena for which people use terms like witchcraft or sorcery. Almost anything seems to be possible: the stereotype for witches in many parts of Melanesia seem to be that they are 'backwards and ugly' (see Introduction, this volume), but in Thomas Strong's contribution on Eastern Highlands of Papua they are envied because they live in a world that people describe as 'highly ordered, flashy and modern'; Congolese Pentecostals suspect that witches now work through modern technology (Katrien Pype, this volume); but Bjørn Enge Bertelsen shows that they themselves can also be suspected-as in Mozambique where German Pentecostal missionaries were suddenly associated with heinous forms of occult violence. Such mulitformity that, moreover, is in constant movement reminds us of James Siegel's seminal insight that witchcraft connects things that should notor even cannot-be connected, or of Michael Taussig's evocation of the

P. Geschiere $(\square)$

University Of Amsterdam, Amsterdam, The Netherlands

(C) The Author(s) 2017

K. Rio et al. (eds.), Pentecostalism and Witchcraft, Contemporary

Anthropology of Religion, DOI 10.1007/978-3-319-56068-7_12 
power of 'the murky' (Siegel 2006; Taussig 1987). It is, therefore, most fortunate that the Introduction does not try to come to a more or less closed analysis imposing a neat order on such exuberance. The editors rather content themselves to outline certain trends and recurring patterns without freezing that which is constantly shifting.

It is also due to such openness that the regional comparison in this volume-between Africa and Melanesia-works. Of course, such regional comparisons are always risky. An obvious danger is that they lead to stereotypical regional contrasts, and the Africa/Melanesia twinning has some history in this respect. It is interesting to try and understand why this comparison seems to have such attraction for anthropologists, ever since J.A. Barnes' much contested warning against applying African kinship models in the New Guinea highlands (Barnes 1962). Also comparisons on other aspects—for instance, Marwick's 1964 stereotyping of African witchcraft as an inside affair in contrast to sorcery in Oceania as coming from the outside-show a clear tendency to produce binary oppositions, that subsequently are bound to be demolished by colleagues working within each of the regions concerned. ${ }^{1}$ Therefore, it is reassuring to see that in this collection, differences cut right through regional boundaries. An overview of the various chapters makes it, indeed, quite hard to conclude that there is something like a Melanesian ontology (let alone an African one).

The collection escapes all the more from the danger of presenting the two regions as blocks since it focuses the comparison on a theme that is both specific and general (at least it is becoming ever more general): the articulation of Pentecostal movements and local forms of knowledge. And on this point all the articles do converge, highlighting one paradoxical trend. Pentecostalism-which is, of course, a panacea term for all sorts of different movements that moreover are constantly splitting up-is victorious because it presents itself as capable of eradicating witchcraft. However, this means in practice that it reinforces the very 'witchcraft' it claims to eradicate. In all the contributions, Pentecostal movements feed on people's fears of hidden aggression, offering relief but at the same time fanning such fears, evoking new and often unheard occult threats. Tom Bratrud shows how child prophets and their attacks on sorcery in Vanuatu emerge from a complex relation with Pentecostal Christianity: it seems to be a relation of opposition but in practice is one of mutual reinforcement. For me, the old notion of articulation works wonderfully well to express such a paradox, precisely because it implies 
that this is a two-sided process. It may be tempting to see the protagonists of new forms of Christianity with their crusades against local witchcraft/sorcery as the main actors. But the action is two-sided, the new religious fervor becoming entangled in local imaginations. Knut Christian Myhre brings out a similar multi-sidedness in his study of albino murders and other witchcraft practices in the Kilimanjaro region (Tanzania) by his notion of 'folding': "Catholicism and Pentecostalism fold into each other to fold out of witchcraft and alternatively fold out of each other as inversions or reversals of one another." A challenging image that asks for detailed, historical studies of how these articulation processes evolved over time: witchcraft, Catholicism and Pentecostalism in their mutual involvement constantly generating new links and oppositions. As challenging is his plea to get beyond a preoccupation with representation (one form of action acting upon the other) but rather to study the relation between Christianity and witchcraft as a relation of 'equivalence'-that is, each modifying the other. ${ }^{2}$ Myhre's suggestion to "to allow vernacular actions to act on our [academic] practices and our representational powers" is indeed an urgent one for this whole domain in which the danger of academic interpretations losing contact with people's understandings of how occult forces intervene in their everyday life is particularly great. I certainly agree we must allow for such openness but I would add that we have then also to accept this will have its costs (see below).

In African studies, the paradoxical articulation between Pentecostalism and witchcraft — opposing each other, yet mutually reinforcing — has been observed already for some time (Meyer 1999; Marshall 2009, and many others). It is powerfully condensed in Sasha Newell's notion 'Pentecostal witchcraft' (2007) quoted in several chapters. But, mixing examples from very different regions, this collection highlights again quite different implications of this general amalgamation. For Barbara Andersen's nursing students-upcoming members of an educated elite in Papua New Guinea-Pentecostalism brings relief for practical problems, just as in Michelle MacCarthy's study of Trobrianders embracing Pentecostalism as a protection against 'the old ways.' But for Koen Stroeken, his experiences in Tanzania and Congo rather point to a flattening and a destruction of finely tuned distinctions of the spiritual realm of olden days - a flattening in which anthropologists would have joined for some time already. For Ruy Blanes, the ndoki (sorcery) has become a kind of spiritual index for Pentecostal leaders in Angola, comparable to the Dow Jones in economics. Annelin Eriksen and Knut Rio show how the new 
Pentecostal religious regime in Porta Vila, the rapidly growing capital of Vanuatu, creates novel fears among the population for a proliferation of novel forms of magic, often with a global background. For Katrien Pype, Pentecostalism seems to have become already a self-evident presence in Kinshasa. Comparing different Pentecostal currents she emphasizes their openness to new developments: in contrast to the classic 'variants' her Branhamist Pentecostals, still preoccupied with kindoki (witchcraft), are preoccupied less by its rural background but more by its appearances in modern technology.

Yet, underneath such a flux of variations, there is again a general line, rightly emphasized by Rio, MacCarthy, and Blanes in their introduction: the complex articulation of Pentecostalism and witchcraft means that the universalizing tenor of the former affects also the latter. Rather than eradicating it, Pentecostalism seems to universalize witchcraft by equating it with the devil, a cosmic figure par excellence. On this point, again omnipresent in this book, it is interesting to compare with the work of Joseph Tonda, a Congolese anthropologist, now in Libreville (Gabon), who works on the entanglement of Pentecostal and local forms of healing already since the early 1990s, but whose works has unfortunately not (yet) been translated into English. ${ }^{3}$ Tonda has challenging things to say on the interaction between outside influences and local forms of knowledge/perception in Africa ever since the colonial period. He criticizes current views on Africa-also among social scientists and historians-as being marked by the idea of 'the Great Divide': the tendency to oppose, on the one hand, the impact of external factors like the world market, the state and most of all le travail de Dien (the work of God = the mission) and, on the other, l'esprit sorcellaire (the witch-spirit). In these current views, the latter is then diagnosed as the real cause of the ongoing crisis in Africa. Over and against such a diagnosis, Tonda develops his powerful vision of one big steaming stream of magma in which all different factors blend. From this nondescript mass emerges the frightening figure of Le Souverain moderne - the Leviathan of postcolonial Africa - that Tonda sees as the real cause of Africa's plight (Tonda 2005). Tonda's visionary interpretations are clearly marked by his own horrible experiences of the civil war in Brazzaville in the 1990s which was one of the most violent on the continent since it took place inside the citya drawn-out war of trenches in which the citizens were at the mercy of warlords and their mercenaries who had dug themselves in, each in one-quarter of the city. Tonda strongly opposes a tendency among 
anthropologists to interpret the emergence of such frightening leader figures in terms of 'traditional' continuities. For him, it is impossible to separate 'traditional' and 'modern' elements. These souverains modernes are as much products of processes of commoditization triggered by the inclusion in global market exchanges - and, indeed, their consumerism is proverbial-, by the authoritarianism of the colonial state and by the missionaries' effort to create a new elite.

Even more importantly is Tonda's warning that present-day 'traditions' have been completely recreated under the colonial impact. In this respect as well, his views are most challenging by their rigor. Especially for what people now call 'witchcraft' he is adamant: people may see this as a tradition but it has been completely recreated and turned inside out by the colonial moment. So, it is futile to oppose le travail de Dieu to local ideas about occult power. The missionaries may have seen themselves as crusaders against witches and witch-doctors, but what they produced is an assemblage in which religion and witchcraft are inherently entangled. The parallel with Newell's notion of 'Pentecostal witchcraft' quoted above may be clear. Also, Eriksen and Rio's analysis of a Pentecostal movement capturing Port Vila's population by evoking novel forms of occult dangers corresponds very well to Tonda's vision. In this 2002, book La guérison divine en Afrique centrale (Divine Healing in Central Africa) the latter follows a jumble of healers-men and women, old and young, educated and rural-who are quite difficult to classify. Nganga ('traditional healers') are in fierce competition with evangelical ones, but they constantly borrow from each other, or even transmute into the other category. In practice, Christian healers have to relate to the very forces they claim to combat. But, vice versa, the very name of 'traditional healer' becomes ironical because their practice is so deeply marked by the changing context.

With Tonda this colonial recreation of 'witchcraft' sometimes seemed to be a quite sudden process. Marshall (2009: 35-38) is even more explicit on this point. Always in for some anthropologists-thrashing, she insists that we have to study this turn as an 'event' in the Foucauldian sense- 'a relation of forces which is inversed, a power confiscated, a vocabulary appropriated and turned against its users...'. The challenge is to look at it as a new beginning, not allowing us to be burdened by the anthropological proclivity to look for continuities underneath all changes. ${ }^{4}$ It might be worthwhile, though, to emphasize that this colonial 'moment' was a longer process. Of course, in many parts of Africa, 
the colonial presence was fairly short. Many areas were only fully 'pacified' in the 1920s, and already in the 1950s independence was already announcing itself. But still, the articulation of local ideas with, for instance, le travail de Dieu was a process which often followed a rocky trajectory. For Africa, the most interesting recent developments in the field of 'witchcraft studies' are by scholars-both historians and anthropologists, who take this idea of articulations following specific historical trajectories seriously. As noted in the Introduction to this volume, the long-term debate about the pro's and contra's of using terms like 'witchcraft,' 'sorcery' or sorcellerie — kind of Gordian knot, since these are, of course, distorting western translation of local notions, yet now generally used and appropriated by the population-might be solved in a practical way by such historical studies of how the western terms were introduced: how they became accepted as an ever more current translation of a local term, and how in this process both notions mutually transformed each other. A good example is Andrea Ceriana Mayneri's recent book (2014) on the 'imaginary of dispossession' among the Banda of Central African Republic. A central moment in the book is how the term sorcellerie was introduced in a discussion of a French administrator, baffled by the local notion of ondro, with a local chief and a missionary who talked about sorcellerie; the most important role was (as usual) played by a local interpreter who simply used both terms as equivalents. In his book, Ceriana Mayneri follows the implications of this working misunderstanding for the two notions involved. In her forthcoming book, Florence Bernault follows a related trail by focusing on the convergences between the imaginaries of French colonials and locals in Gabon. Again, both the people involved and many subsequent scholars tend to assume a self-evident opposition here. But Bernault shows that the French struggled with assumptions about spirits and their elusiveness that related in practice very well to the locals' images, while for the latter it was obvious that the French became ever more entangled in the local imaginary.

Such detailed unraveling of historical articulations and their specific trajectories might suggest directions for taking the challenging comparisons in the present collections even further. For one thing, it might be important to place the very idea of 'Pentecostal witchcraft' in a longer time perspective. Present-day articulations of this 'mutually reinforcing relation' are part of a much longer process in which Christianity in its more intolerant forms was confronting local beliefs. In the forest area of southeast Cameroon, where I did my main field-work present-day 
Pentecostal fervor seems to bring in some respects a return to the early days of conversion (first decades of the twentieth century) when both Protestant and Catholic missionaries seemed to aim at instituting a sort of theocracy, drawing their converts to the mission post, and imposing a radical regime in order to distance their flock from heathen surroundings - this to the great dismay of colonial administrators who wanted to retain people (and their labor force) for their own projects.

Another interesting alley is opened up by Katrien Pype with her seminal emphasis on technology and science as a new focus in the Pentecostal struggle against witchcraft. Again this evokes a longer struggle. It relates very well to Ceriana Mayneri's emphasis that as long as we can go back, local discourses on occult power where 'provoked' by western scientific discourse - a provocation that led to such determined efforts toward fusion that any idea of a binary opposition becomes futile. Of course, it is standard to oppose Western science as transparent and rational to African (or Melanesian) occultism as murky and irrational. But to the people involved such a contrast is often untenable. 'Traditional' healers will boast of their science and people claim that at night their witches use technology that outdoes by far western equivalents. 'Our planes do Paris and back in one night' as my friend in the village often repeated. And one of the modern nganga - who claimed to have a medical degree-was supposed to be particularly successful because he was so good at destroying 'nocturnal air strips' so that the witches' planes could no longer land. ${ }^{5}$ People's discourses on occult power have developed for over a century now-and in many areas even longer-in a context where western medicine, technology, and theology were highly present. But this did not lead to an either/or conflict but rather to complex and volatile articulations and assemblages. It is, therefore, important to realize that our informants' discourse on the occult is developing in a long-term articulation with western ideas, not in radical opposition but rather inspiring efforts towards blending and fusion. Tonda's image of a magma-in-flux is very relevant in this respect as well. But despite all this blending-fusing what appears to be separated-the challenge is to study even this diffuse magma as a conglomerate of specific historical trajectories over a longer period of time.

Tonda's magma notion raises similar issues as Michael Taussig's earlier explorations of the power of 'epistemic murk' (Taussig 1987). When I was reading through this collection Taussig's powerful image kept coming back to my mind. Indeed, it seems to be their very fuzziness, allowing 
for all sorts of explanations, that is important for understanding the resilience of these shifting imaginaries on occult forces, and their capacity to graft themselves upon incisive changes. In Pype's study on Kinshasa, these hidden forces invade new technologies; Eriksen and Rio show that objects from Africa can suddenly become central to horror stories in Port Vila; for Thomas Strong witches in Papua New Guinea evoke jealousy because of their 'ordered modernity.' For Koen Stroeken such volatility seems to be a deplorable effect of modern changes-like the impact of Pentecostal missionary zeal-destroying fine-grained distinctions ordering local society. In my experience, this diffuseness and chameleonic capacities are rather given with basic trends in the discourse on occult powers. The central concern in many 'witchcraft' discourses with dramatic, nightly confrontations place a premium on novel borrowings that can surprise adversaries. Hence their basically unstable and shifting character and a basic ambiguity on what is good and evil: the nganga as a healer can always be suspected to turn into a witch. The idea that the same power that can heal can also kill, returns in a wide range of settings. Or, to be more concrete, nganga may be healers for their clients, but the witch they attack will claim to be an innocent victim of healers who are themselves witches. Such shifts are also crucial in the interaction of these ideas with Pentecostalism. To these preachers the 'traditional healer' is, of course, a witch-no doubt about that-but this certainty is constantly being undermined by the basic ambiguity of local ideas. As many of the Ghanaian and Nigerian video-films, deeply marked by the Pentecostal message, highlight: the treason may be inside-the most fervent crusader can turn out to be a source of evil (Meyer 2015). It is the shifting character of these imaginaries, marked by deep ambiguities and uncertainties, that make them so resilient despite deep changes.

All this to argue that Knut Myhre's plea for allowing "vernacular actions to act on our [academic] practices and our representational powers" is highly sympathetic but raises also serious dilemmas. It certainly raises enticing perspectives: it is vital not to lose touch with people's ways of seeing things or to try to reduce these to another, more 'real' reality. But it raises also a basic dilemma for us academics. One of the first principles of academia is that we must create clarity, working as much as we can with unequivocal notions. But how to deal then with forms of knowledge that get their power precisely from their un-clarity and their ambiguity? How can we avoid that our efforts to create clarity abscond the very power we are trying to understand? Taussig's solution 
for gaining insight into the power of the murky was to go along with all these ambiguities: taking the drugs and using his feverish revelations to experience the deep ambiguity and unexpected linkages of this hidden world. I am not reproaching the authors for not following this example. Taussig's book, the sediment of his adventurous journey, is fascinating but also mind-boggling; Tonda's books have the same visionary quality. But we must be aware of the tension between striving for clarity and opening up to the full ambiguities of people's thinking about the invisible forces. The great merit of this collection is that it gives full reign to such transgressive exuberance, not fixing it in an all too firm analytic grid.

\section{Notes}

1. See for a recent and spirited defense of anthropology's comparative method (van der Veer 2016).

2. In my view such a double-sided articulation-the impact of global economic changes being profoundly affected by people's imaginaries of occult forces, but the latter in turn provoked by such changes-was exactly what Jean and John Comaroff had in mind with their notion of 'occult economies,' Myhre's main target. But the plea for a view in terms of 'an action upon an action' is of course most welcome.

3. Seagull Press is now preparing a translation of Tonda's Le Souverain moderne.

4. See for a similar view from Melanesia, Robbins (2007)

5. Cf. Geschiere (1997); see also Lattas (2010) for New Britain.

\section{REFERENCES}

Barnes, J.A. 1962. African Models in the New Guinea Highlands. Man 62: 5-9. Bernault, F. forthcoming. Struggles for the Sacred: Power and Fantasy in Colonial Gabon. Durham: Duke U. P.

Ceriana Mayneri, A. 2014. Sorecllerie et prophétisme en Centrafrique: L'imaginaire de la dépossession en pays banda. Paris: Karthala.

Geschiere, P. 1997. The Modernity of Witchcraft, Power and the Occult in Postcolonial Africa. Charlotsville: University of Virginia Press.

Lattas, A. 2010. Dreams, Madness and Fairy Tales in New Britian. Durham: Carolina Academic Press.

Marshall, R. 2009. Political Spiritualities: The Pentecostal Revolution in Nigeria. Chicago: University of Chicago Press. 
Marwick, M. 1964. Witchcraft as a Social Strain Gauge. Australian Journal of Science 26: 263-268.

Meyer, B. 1999. Translating the Devil-Religion and Modernity among the Ewe in Ghana. Edinburgh: Edinburgh University Press for International African Institute.

- 2015. Sensational Movies-Video. Vision and Christianity in Ghana. Berkeley: California Press.

Newell, Sasha. 2007. 'Pentecostal Witchcraft: Neoliberal Possession and Demonic Discourse in Ivoirian Pentecostal Churches'. Journal of Religion in Africa 37 (4): 461-490.

Robbins, J. 2007. Continuity Thinking and the Problem of Christian Culture: Belief, Time, and the Anthropology of Christianity. Current Anthropology 48 (1): 5-38.

Siegel, J. 2006. Naming the Witch. Stanford: Stanford U.P.

Taussig, M. 1987. Shamanism, Colonialism and the Wild Man: A Study of Terror and Healing. Chicago: University of Chicago Press.

Tonda, J. 2002. La guérison divine en Afrique centrale (Congo, Gabon). Paris: Karthala.

- 2005. Le souverain moderne: Le corps du pouvoir en Afrique centrale (Congo, Gabon).Paris: Karthala.

Van der Veer, P. 2016. The Value of Comparison. Durham: Duke U.P.

\section{Author Biography}

Peter Geschiere is Professor of Anthropology at the University of Amsterdam, fellow of the Royal Netherlands Academy of Sciences and co-editor of the journal ETHNOGRAPHY (with SAGE). Since 1971 he has undertaken historical-anthropological field-work in various parts of Cameroon and elsewhere in West Africa. He has published extensively on issues of citizenship, belonging and exclusion (see, for instance, his 2009 book with University of Chicago Press, Perils of Belonging: Autochthony, Citizenship and Exclusion in Africa and Europe). Another central topic in his work is the relation between witchcraft and politics in Africa and elsewhere. This has resulted in The Modernity of Witchcraft (University of Virginia Press 1997) and Witchcraft, Intimacy and Trust-Africa in Comparison (University of Chicago Press 2013). 
Open Access This chapter is licensed under the terms of the Creative Commons Attribution 4.0 International License (http://creativecommons.org/licenses/ by $/ 4.0 /)$, which permits use, sharing, adaptation, distribution and reproduction in any medium or format, as long as you give appropriate credit to the original author(s) and the source, provide a link to the Creative Commons license and indicate if changes were made.

The images or other third party material in this chapter are included in the chapter Creative Commons license, unless indicated otherwise in a credit line to the material. If material is not included in the chapter Creative Commons license and your intended use is not permitted by statutory regulation or exceeds the permitted use, you will need to obtain permission directly from the copyright holder.

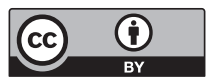

